\title{
CAMBRIDGE
}

\section{The Cambridge History of American Literature}

Volume I: $1590-1820$

\section{Edited by SACVAN BERCOVITCH}

The Cambridge History of American Literature addresses the spectrum of new and established directions in American writing, wedding the voice of traditional criticism with the diversity of interests that characterise contemporary literary studies. Volume I covers the colonial and early national periods, discussing authors ranging from Renaissance explorers and Puritan theocrats to the poets and novelists of the new republic.

f55.00 net HB $052130105 \times 845 \mathrm{pp}$.

\section{A Cultural History of the American Novel}

Henry James to William Faulkner

DAVID MINTER

Minter's broad and synthetic vision of the relationship between literary narratives and cultural events reconstructs literary history as a cultural drama in which the novels and the events, provocative fusions of the real and the imagined, emerge as kindred forms of cultural expression.

$£ 37.50$ net $H B \quad 0521452856 \quad 292 \mathrm{pp}$

\section{The Politics and Poetics of Journalistic Narrative}

The Timely and the Timeless

PHYLLIS FRUS

Frus's book tells the story of the separation of journalism from literature (Crane and Hemingway) in the early 20th century, and discusses the narratives that resulted when fiction and nonfiction appeared to merge again in the innovative journalism of the $1960 \mathrm{~s}$ and 70 s (Mailer, Capote, Wolfe, Janet Malcolm).

f37.50 net HB $0521443245 \quad 318$ pp.

\section{African American Theatre}

An Historical and Critical Analysis

SAMUEL A. HAY

This book traces the history of African American theatre from its beginnings to the present. It analyses the types of plays written for this theatre, identifies the perennial problems faced by theatre artists and producing companies, and makes bold, innovative proposals for the theatre's healthy survival.

f37.50 net HB $0521445221 \quad 303$ pp.
f13.95 net PB 0521465850
Cambridge Studies in American Theatre and Drama 1

Cambridge Studies in American Theatre and Drama 1

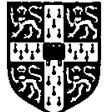

\section{CAMBRIDGE UNIVERSITY PRESS}

The Edinburgh Building, Cambridge CB2 2RU 


\section{CAMBRIDGE}

\section{William Carlos Williams and Alterity}

The Early Poetry

BARRY AHEARN

Many critics have noticed the paradoxes and contradictions in the work of William Carlos Williams, but few have analyzed them in detail. Professor Ahearn argues that Williams criticism has not gone far enough in recognising the uses Williams saw for contradiction.

E30.00 net HB $0521452007 \quad 199 \mathrm{pp}$.

Cambridge Studies in American Literature and Culture 75

\section{Poetics of the Feminine}

Authority and Literary Tradition in William Carlos Williams, Mina Loy, Denise Levertov and Kathleen Fraser

LINDA A. KINNAHAN

This book examines the early work of William Carlos Williams in relationship to a woman's tradition of American poetry, as represented by Mina Loy, Denise Levertov and Kathleen Fraser - three generations of women poets working in or directly from a modernist tradition. Linda Kinnahan traces notions of the feminine and the maternal that develop as Williams seeks to create a modern poetics.

f37.50 net HB $0521451272302 \mathrm{pp}$.

Cambridge Studies in American Literature and Culture 74

\section{The Baroque Narrative of Carlos de Siguenza y Gongora} A New World Paradise

\section{KATHLEEN ROSS}

This book is the first critical study to place both the writer and his narrative within the phenomenon of the Barroco de Indias, or the Spanish-American baroque. Approaching Siguenza as criollo historian preoccupied with the placement of the New World within a universal context, Professor Ross develops a theoretical framework within which his texts can be read and understood today.

f35.00 net HB 0521451132240 pp.

Cambridge Studies in Latin American and lberian Literature 9

\section{The Limits of American Literary Ideology in Pound and Emerson \\ CARY WOLFE}

Cary Wolfe analyses the dynamics and consequences of radical individualism and the sort of cultural critique it generates in Ralph Waldo Emerson and Ezra Pound. The main purpose of the book is to demonstrate that any form of individualism which is modelled on the logic and structure of private property will always reproduce the very contradictions and alienations which it set out to criticise and to remedy.

£35.00 net HB $0521445558 \quad 301$ pp.

Cambridge Studies in American Literature and Culture 69

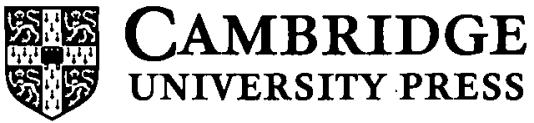

The Edinburgh Building, Cambridge CB2 2RU 


\section{CAMBRIDGE}

\section{Nathaniel Hawthorne}

The Contemporary Reviews

Edited by JOHN IDOL and BUFORD JONES

Preface by M. THOMAS INGE

This collection traces the construction of Hawthorne's contemporaneous critical reputation as presented through notices and reviews, a selective bibliography, and an introduction that surveys Hawthorne's reception among American and British reviewers.

E65.00 net HB $0521391423560 \mathrm{pp}$.

American Critical Archives 4

\section{New Essays on The Country of the Pointed Firs}

\section{Edited by JUNE HOWARD}

This collection of essays on Sarah Orne Jewett's The Country of the Pointed Firs, builds on feminist literary scholarship that affirms the value of Jewett's work, but goes beyond previously published studies by offering an analysis of how race, nationalism, and the literary market place shape her narrative.

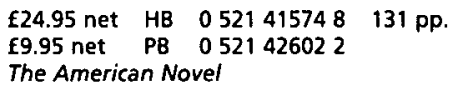

\section{Hollywood Censored}

Morality Codes, Catholics, and the Movies

\section{GREGORY D. BLACK}

Based on an extensive survey of original studio records, censorship files, and Catholic Legion of Decency archives here published for the first time, Hollywood Censored examines how hundreds of films were censored to promote a conservative political agenda during the 1930s, the golden era of studio production.

f 30.00 net HB $0521452996 \quad 347 \mathrm{pP}$.

Cambridge Studies in the History of Mass Communications

\section{Frederic Edwin Church}

Catalogue Raisonné of Works of Art at Olana State Historical Site

\section{GERALD L. CARR}

This is the largest project thus far undertaken on Frederic Edwin Church: a comprehensive scholarly catalogue of his works of art still at Olana State Historical Site.

f250.00 net HB $0521385407 \quad 635$ pp.

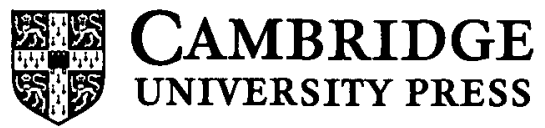

The Edinburgh Building, Cambridge CB2 2RU 


\section{Stand \\ in the Center \\ of the Good \\ Interviews with \\ Contemporary \\ Native American \\ Artists \\ Lawrence Abbott \\ $£ 38 \mathrm{hb}$ \\ Chief \\ The Life History of \\ Eugene Delorme, \\ Imprisoned Santee Sioux \\ Edited by \\ Inéz Cardozo-Freeman \\ $£ 24.95 \mathrm{hb}$}

\section{South Carolina \\ Politics and \\ Govemment}

Blease Graham, Jr. and William V. Moore

$£ 42.75 \mathrm{hb}, £ 16.95 \mathrm{pb}$

\section{North Carolina \\ Govemment and Politics}

Jack D. Fleer

$£ 38 \mathrm{hb}, £ 17.95 \mathrm{pb}$

\section{Democracy}

in the Fifty States

Kim Quaile Hill

$£ 28.50 \mathrm{hb}$

\section{The Life of}

\section{Abraham Lincoln}

Isaac N. Arnold

Introduction by

James A. Rawley

$£ 11.95 \mathrm{pb}$

\section{Recollections of}

Abraham Lincoln,

\section{7-1865}

Ward Hill Lamon

$£ 11.95$

\section{Such Men}

\section{as Billy the Kid}

The Lincoln County War

Reconsidered

Joel Jacobsen

"The engaging narrative will please and provoke scholar, well-versed buff, and newcomer alike."

-Library Journal

$£ 26.50 \mathrm{hb}$

\section{The Oregon Trail}

Francis Parkman

Edited by E. N. Feltskog

$\# 21.50 \mathrm{pb}$

\section{The Conspiracy of}

\section{Pontiac and the} Indian War after the Conquest of

\section{Canada}

Volume 1: To the

Massacre at

Michillimackinac

Volume 2: From the

Spring of 1763 to the

Death of Pontiac

Francis Parkman

Introduction by

Michael N. McConnell

Volume 1: $£ 11.50 \mathrm{pb}$

Volume 2:£11.50

\section{Lone Wolf $v$.}

Hitchcock

Treaty Rights and Indian

Law at the End of the

Nineteenth Century

Blue Clark

E35 hbEdited by

Dorothy Lamon Teillard

Introduction by

James A. Rawley

$£ 35 \mathrm{hb}$

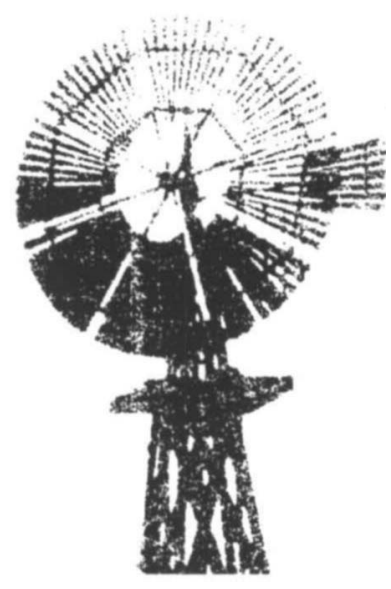

Talking Up a Storm

Voices of the New West Gregory L. Morris

Morris interviews fifteen writers of the New West.

£23.95 hb

Willa Cather Scholarly

Editions

\section{My Ántonia}

Edited by Charles

Mignon with

Kari Ronning

Historical essay and

explanatory notes

by James Woodress

Illustrations by

W.T. Benda

$£ 52.50 \mathrm{hb}$

\section{Remember \\ Laughter}

A Life of James Thurber

Neil A. Grauer

$\mathrm{E} 19 \mathrm{hb}$ 


\section{Within the Circle}

An Anthology of African American Literary Criticism from the Harlem Renaissance to the Present

Angelyn Mitchell, editor

"Within the Circle is essential reading for anyone interested in American literature, twentieth-century cultural criticism, or the African American intellectual canon. It belongs on every bookshelf and, more important, as required reading within the American literature classroom." - Cathy $N$.

Davidson, editor of American Literature 584 pages, $£ 47.95 \mathrm{hb}, £ 17.95 \mathrm{pb}$

\section{The First Woman in the}

\section{Republic}

A Cultural Biography of

Lydia Maria Child

Carolyn L. Karcher

"This is a magnificent book. Child's character emerges as a model for twat a woman can be ... With Chíld in the foreground, the American nineteenth century stands revealed anew - in all its idealism, violence, ugliness, and splendor. : Jane Tompkins, author of West of Everything. New Americanists 928 pages, 10 b\&w photos, $€ 35.95 \mathrm{hb}$

\section{Constituting Americans}

Cultural Anxiety and Narrative Form

\section{Priscilla Ward}

Ever since the foundes drafted "We the People," "we"rove been at pains to work out the contoradietions in their formulation, to fix in words precisely what it means to be American.

Constituting Americans rethinis the way that certain writers of the mid.

nineteenth and early twentieth centrity contributed to this project; in domg so. it revises the traditional narrative of U.S. literary history, restoring essential chapter to the story of an emerging American cultural identity. New Americantsts 368 pages, f16.95 85

\section{The Long War}

The Intellectual People's Front and Anti-Stalinism, 1930-1940 Judy Kutulas

The Long War offers a new, informed perspective on the intellectual maneuvers of the American left of the 1930 s and leads to a reinterpretation of the time and its complex legacy. 320 pages, £37.95 hb, £16.95 pb

\section{Half Sisters of History}

Southern Women and the American Past

\section{Catherine Clinton}

Long relegated to the margins of historical research, the history of women in the American South has rightfully gained prominence as a distinguished discipline. This volume, a comprehensive and much needed tribute to southern women's history. brings together the most important work in this field over the past twenty years. 256 pages, $£ 41.50 \mathrm{hb}, £ .4 .95 \mathrm{pb}$

\section{From Cotton Belt to}

\section{Sunbelt}

Federal Policyand Economic

Developnient. ant the

Transformation of the south, 1938-1980

Broter. 1 Sonutman 352 . ages 2000100

\section{Contested Boundaries}

Itinerand ond ye Reshiping ol the Colontal Anerican Religious Worlo Timothy 0 \%oti. 200 pases. 637.95 hb. 6.15 .95 pb

\section{DUKE}

\section{Wuersy pross}

co Acadonico. University

Publusters. Group

Gowerstreet

Bordor. WOE. $61 \mathrm{~A}$ 


\section{Invisible Darkness}

Jean Toomer and Nella Larson

Charles R. Larson

"Invisible Darkness unearths new

information about the so-called lost years of Toomer and Larson. It also highlights the problematic nature of their relationship to the Harlem Renaissance and to black culture in general." - Wilson Library Bulletin 240 pages, 10 photos, $€ 32.95 \mathrm{hb}, \epsilon 13.95 \mathrm{pb}$

\section{Walt Whitman}

The Centennial Essays

Edited by Ed Folsom

Drawings by Guido Villa

"This collection gathers the current state of Whitman scholarship from the most influential Whitman critics working over the past half century." - Ed Folsom, from the introduction 296 pages, 5 drawings, Ł3I.50 hb, $\& 16.95 \mathrm{pb}$

\section{Garrison Keillor}

Peter A. Scholl

"Scholl's in-depth study draws parallels between Keillor's public career as a radio performer and his solitary life as a writer. Scholl calls it 'Keillor's duality, his doubleness. There is the celebrity and private citizen, the writer and the performer... Scholl was given complete access to the Minnesota Public Radio archives, and spent hours listening to reelto-reel tapes and reading scripts. He also corresponded with and interviewed Keillor associates and interviewed the man himself." - Waterloo Courier 276 pages, $E I I .95 \mathrm{pb}$

\section{Anne Tyler as Novelist}

\section{Edited by Dale Solwak}

The seventeen essays that compose this volume, concentrate upon the distinctive features of Tyler's writing: her steady concern with the American family, the quietly comic touch that underlies her unobtrusive but perfectly controlled style, and her prodigious gift for bringing to life a variety of eccentric characters, their fears and concerns, their longing for meaning and understanding. 240 pages, $£ 28.50 \mathrm{hb}, € 13.95 \mathrm{pb}$

\section{The Last Word}

Letters Between Marcia Nardi and William Carlos Williams

Edited by Elizabeth Murrie O'Neil

"This correspondence illuminates both the desperation of a woman poet seeking a language and a literary place that continued to elude her and the use a male poet made of her talent and desperation. An essential book for Williams scholars and for feminists." - Carolyn G. Heilbrun 292 pages, 9 photos, $\notin 32.95 \mathrm{hb}, \in 15.95 \mathrm{pb}$

\section{My Life with President}

\section{Kennedy}

\section{Christopher Clausen}

"Clausen remains one of the clearest thinking of our cultural critics. The reflections that he offers here are set instructively within an informed and engaging perspective ... The result is a most provocative gathering: keen insights, fine writing." - Stanley Lindberg 128 pages, $Q 21.95 \mathrm{hb}, £ 9.50 \mathrm{pb}$ 


\section{Poor Fool}

A Novel by Erskine Caldwell

Voices of the South

An early novel by a master of the southern grotesque. $155 \mathrm{pp}, £ 9.50 \mathrm{pb}$

\section{The Last of the}

\section{Southern Girls}

A Novel by Willie Morris

Voices of the South

"Willie Morris has written a witty,

intelligent, and engaging book

about Washington ... As a roman

a clef it is great fun." - The New

Republic $304 \mathrm{pp}, £ 10.95 \mathrm{pb}$

\section{The Morning and the}

\section{Evening}

A Novel by Joan Williams

Voices of the South

"The Morning and the Evening is indisputably the work of a greatly gifted writer. It is a haunting and beautiful tale, richly interfused with humor and sharp, unsettling insights into the human predicament." - William Styron $248 \mathrm{pp}, £ 10.95 \mathrm{pb}$

\section{Folk Roots and Mythic} Wings in Sarah Orne Jewett and Toni Morrison

The Cultural Function of Narrative Marilyn Sanders Mobley

"This is a richly suggestive study, a persuasive and valuable contribution to the reconceptualizing of the American literary canon."

- American Literature

$193 \mathrm{pp}, £ 10.95 \mathrm{pb}$

\section{Purloined Letters}

Originality and Repetition in American Literature Joseph N. Riddel

Edited by Mark Bauerlein

An eminent theorist addresses the problem of "American" literature. 232pp, £28.50hb

\section{A Certain Slant of Light}

Regionalism and the Form of Southern and Midwestern Fiction David Marion Holman

Introduction by Louis D. Rubin Jr. Southern Literary Studies An innovative study of the connection between regional awareness and imaginative achievement in the South and Midwest. $160 \mathrm{pp}, £ 23.95 \mathrm{hb}$

\section{The Novels of William \\ Styron}

From Harmony to History

Gavin Cologne-Brooks

Southern Literary Studies

This first full-length critical analysis of this major American novelist, uses the concept of narrative evolution, to illumine not only Styron's novels but also an entire genre. 288pp, £28.50hb

\section{LOUISIANA STATE} UNIVERSITY PRESS

c/o Academic \& University

Publishers Group

1 Gower Street

London WC1E 6HA

Tel: 01715803994 
I All contributions and editorial correspondence should be sent to: The Editor, Joumal of American Studies, History Department, Lancaster University, Lancaster LA I 4 YG, England.

2 Articles should generally contain about 6,000 words. Longer or shorter articles, or articles in two or more parts, may be accepted by arrangement with the Editors.

3 Submission of an article is taken to imply that it has not previously been published, and has not been concurrently submitted for publication elsewhere.

4 Contributions should be clearly typed or printed in double spacing (including footnotes), with a wide left-hand margin. Diagrams, maps and illustrations may be included.

5 Spelling may conform either to British or American usage, providing it is consistent throughout.

6 Footnotes should be used sparingly: in general, to give sources of direct quotations, references to main authorities on disputable questions, and evidence relied on for a new or unusual conclusion. They should be numbered consecutively, and may most conveniently be placed, in double spacing, at the end of the article.

7 For guidance on matters of style, contributors should refer either to The Chicago Manual of Style (13th edition, 1982) or to the Joumal of American Studies Style Notes, copies of which may be obtained from the Editors.

8 Contributors should keep one copy of the typescript for correcting proofs.

9 Notes intended for the Editors or Printer should be on a separate sheet.

10 First proofs may be read and corrected by contributors provided that they can give the Editor an address through which they can be reached without delay and can guarantee to return the corrected proofs to the Editor, by airmail where necessary, within three days of receiving them.

I Proof corrections should be kept to an absolute minimum. They should be confined to errors of the typist or printer unless the Editor authorizes otherwise.

12 Contributors of articles and review essays receive 25 free offprints. Extra copies may be ordered according to a scale of charges.

13 Contributors need not be members of the British Association for American Studies. Unsolicited typescripts can only be returned to overseas contributors who send International Reply Coupons (not postage stamps). Typescripts from the UK will not normally be retumed.

14 Contributors of accepted articles will be asked to assign their copyright, on certain conditions, to Cambridge University Press, to help protect their material, particularly in the USA.

Books for review should be sent as follows: History, Political Science and Social Studies to Professor Michael Heale, Department of History, Furness College, Lancaster University, Bailrigg, Lancaster LAi ${ }_{4}$ YG. Literature, the Fine Arts and other books to Professor Richard Gray, Department of Literature, University of Essex, Wivenhoe Park, Colchester 
VOI U M F 29 PAR T I APR IL I 995

In Search of Al Schmid: War Hero, Blinded Veteran, Everyman DAVID A, GERBFR

"A Very Pleasant Patriarchal Life": Professional Authors and Amateur Architects in the Hudson Valley, $1839-1870$ ADAM W. SWEETING

"A Foothold in Europe": The Aesthetics and Politics of American War Cemeteries in Western Europe RON ROBIN

The Issue of State Power: The Council on Foreign Relations as a Case Study

INDERJEET PARMAR

Notes and Comment

The Meeting of Sacred and Profane in New York's Music: Robert Moses, Lincoln Center, and Hip-hop

ANDRÁS TOKAJI

Reviews

Appendix

American Studies in Britain: Doctoral and Masters by Research

Theses on American Topics in Progress and Completed 